\title{
A Mild Methylation of Whole Leaf Producing Per-O-methyl Cellulo Di-phospho Amino Acid (Dipeptide)
}

\author{
Jesus' Christus, Michael Arden Madson \\ Research and Development, BioLogistics Limited Liability Company, Ames, Iowa, United States of America \\ Email address: \\ mmadson53@earthlink.net (M. A. Madson)

\section{To cite this article:} \\ Jesus' Christus, Michael Arden Madson. A Mild Methylation of Whole Leaf Producing Per-O-methyl Cellulo Di-phospho Amino Acid \\ (Dipeptide). Plant. Vol. 8, No. 1, 2020, pp. 10-16. doi: 10.11648/j.plant.20200801.12
}

Received: March 5, 2020; Accepted: March 20, 2020; Published: April 28, 2020

\begin{abstract}
A mild methylation method is detailed in this work. It uses $1 \mathrm{~N} \mathrm{NaOH}$ to deprotonate primary and secondary hydroxyl groups for short time. Excess $1 \mathrm{~N} \mathrm{NH}_{4} \mathrm{OH}(1.00 \mathrm{ml}, \mathrm{pH} 11.4)$ is added, followed by $\mathrm{NaHCO}_{3}$ to make the carbonate esters by nucleophilic substitution of the deprotonated primary and secondary $\mathrm{OH}$ groups. The reaction conditions include; ambient temperature and for an appropriate time. Then $\mathrm{NaBH}_{4}$ is added and the reaction conditions are; standing at ambient temperature for at least 4 hours. This converts the carbonate esters to the methyl ethers. Work-up includes transferring the methylated switchgrass leaf section to a vial containing $1 \mathrm{~N} \mathrm{HCl}(1.00 \mathrm{ml})$. The leaf needs to be submerged in the acid. The reaction conditions include; heating the reaction vessel at $72^{\circ} \mathrm{C}$, for 4 days. The contents of the vial are reduced in volume to syrup with a stream of air. The mixture dissolves completely in methanol. Mass spectrometry is done on a methanol solution in the negative ion ESI mode. The mass spectral interpretation reveals the presence of methylated glucan amimo acids and glucan dipeptides. The molecules identified were per-O-methylated glucans linked to either serine or asparagine through a di-(hydrido) di-phospho di-hydratephe moeity. It is possible that one ion is derived from a phosphorylated tyrosine linked to either the serine or asparagine linked to an originally di-phospho cellulo-glucan.
\end{abstract}

Keywords: Mass Spectrometry, Novel Mild Methylation Method, Cellulo-dipeptides, Per-O-methyl Cellulo-peptides, Glucan-Peptide Linkage

\section{Introduction}

Methylation methods have been used to determine the position of substitution for oligosaccharides and polysaccharides. [1, 2] However, the conditions of most methods require the use of strong base, to ionize methylatable hydroxyl groups on secondary and primary alcohols. The pKa of these groups is $\sim 17$. The $\mathrm{pH}$ of $1 \mathrm{~N}$ $\mathrm{NaOH}$ is, theoretically 14.0 , however commercial $\mathrm{pH}$ meters cannot measure this $\mathrm{pH}$. Typically strong base will cause degradation of carbohydrates. One type of base catalyzed degradation product is the saccharinic acids. [3] This leads to 'peeling' whereby the monosaccharide at the reducing end of the oligo- or polysaccharide is eliminated, 'peeled off'. The method proposed here uses the reduction of carbonate esters to ethers. [4] This is done by making the carbonate esters and then treating the newly formed carbonate ester with $\mathrm{NaBH}_{4}$ in $\mathrm{NH}_{4} \mathrm{OH}$. [5] The reduction of sulfate and phosphate esters is accomplished via this method, as well. [6] These reaction conditions also allow us to isolate glycan-protein linkages for cellulose and their submission to mass spectral analysis and interpretation. [7-10] We also show support for the phosphorylation of tyrosine linked to serine or asparagine to cellulo-glucan. [10-13] There are three bovine glycan-peptide linkages that we have isolated via this method. [14-16]

\section{Materials and Methods}

Switchgrass leaf, freshly harvested, green, was placed in a reaction vessel. $\mathrm{NaOH}(1 \mathrm{~N})$ was added and allowed to stand at ambient temperature for 2 minutes. Then $\mathrm{NH}_{4} \mathrm{OH}(1 \mathrm{~N}, \mathrm{pH}$ $11.4,20$ times the volume of $\mathrm{NaOH}$ ) was added. Solid $\mathrm{NaHCO}_{3}$ was added $(1 \mathrm{mg})$ and the mixture allowed to stand at ambient temperature for two hours. $\mathrm{NaBH}_{4}(3$ microliters of a $4 \mathrm{~N}$ solution) was added and the mixture was allowed to stand at ambient temperature for 20 hours. The resulting leaf section was removed and placed in a vessel containing $\mathrm{HCl}$ $(1 \mathrm{~N}, 1.00 \mathrm{ml})$. The leaf section was completely submerged 
in the acid. The mixture was placed in an oven. The temperature was maintained at $72^{\circ} \mathrm{C}$. After 4 days the reaction vessel was removed from the oven, the leaf was completely dissolved. The solution was evaporated to a syrup with a stream of air. The contents of the vessel were completely soluble in methanol. The sample was analyzed by ESI $\mathrm{ms}$ and $\mathrm{ms} / \mathrm{ms}$ by the Rheinhold group at the University of New Hampshire, USA.

\section{Results and Discussion}

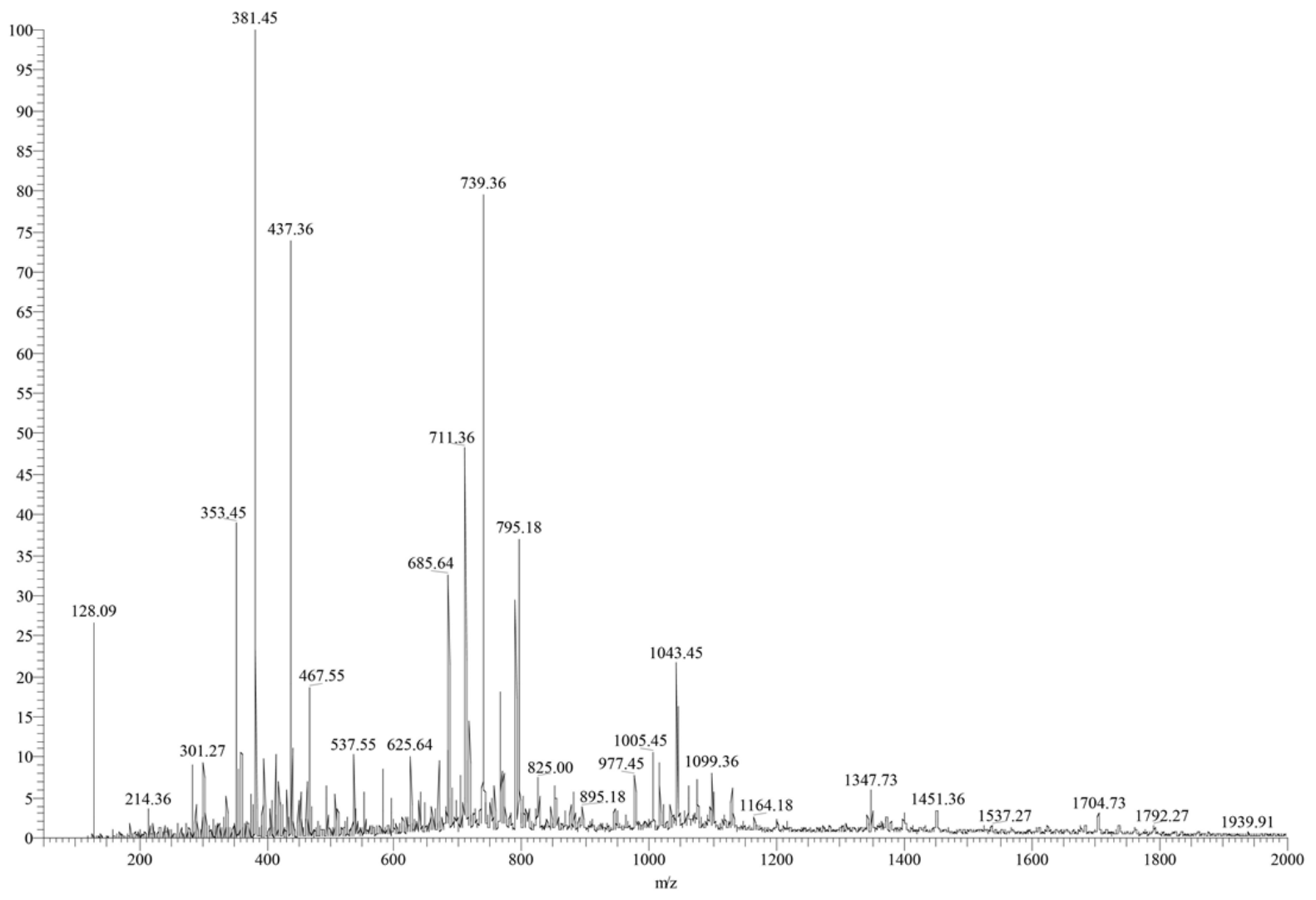

Figure 1. Mass spectrum of per-O-methylated cellulose isolated after novel methylation analysis.

Figure 1 shows the negative ion mass spectrum ESI of the methanol soluble reaction product from switchgrass leaf.

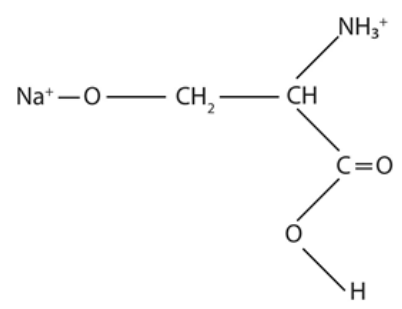<smiles>CO[PH](O)(O)O[PH](O)(O)NC(=O)CCC(N)C(=O)O</smiles>

\section{$\mathrm{C}_{5} \mathrm{H}_{15} \mathrm{~N}_{2} \mathrm{O}_{9} \mathrm{P}_{2}$}

\section{$\mathrm{C}_{3} \mathrm{H}_{7} \mathrm{NO}_{3}\left(\mathrm{Na}^{+}\right)$}

128.06 calculated

128.09 found

$\Delta=0.03 \mathrm{amu}$
$-2 \mathrm{H}^{+}+2\left(\mathrm{Na}^{+}\right)$

353.10 calculated

353.45 found

$\Delta=0.35 \mathrm{amu}$

Figure 2. Serine and asparagine portions of the total molecules. 
In Figure 2 ions, m/z 128.09 and $\mathrm{m} / \mathrm{z}$ 353.45, structures are drawn. They represent the components of the total cellulodipeptides. The ion, $\mathrm{m} / \mathrm{z}$ 128.09, is the zwitterion, $\mathrm{Na}^{+}$salt, of serine. The ion, $\mathrm{m} / \mathrm{z} 353.45$, is derived from di-(hydrido) diphospho di-hydrate asparagine. These are components of O-linked oligosaccharide dipeptide and N-linked oligosaccharide dipeptide.

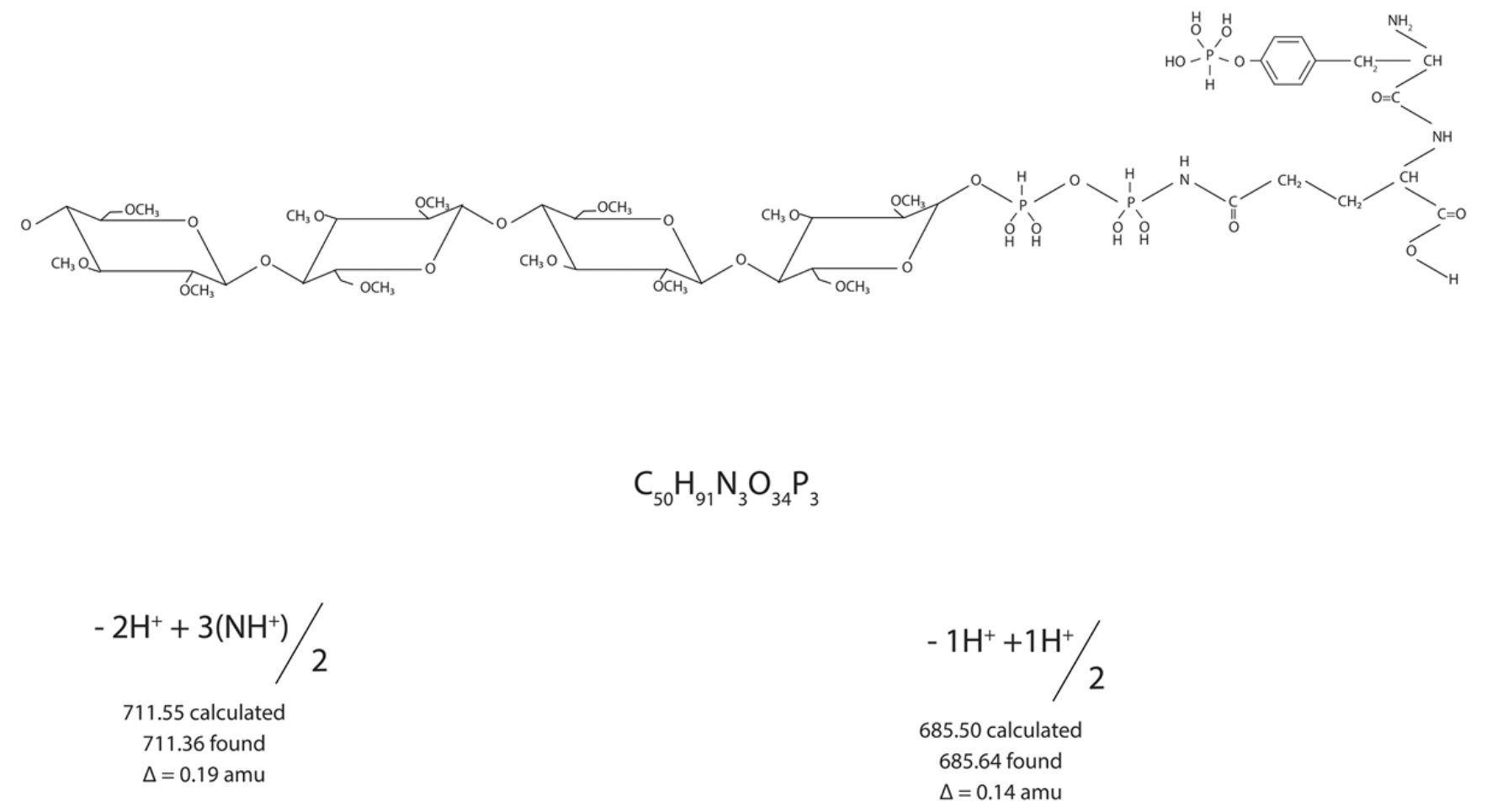

Figure 3. Ions, $\mathrm{m} / \mathrm{z} 711.36$ and $\mathrm{m} / \mathrm{z} 685.64$, are cellotetraose derivatives.

Figure 3 describes pictorially the structure for ion, $\mathrm{m} / \mathrm{z}$ 685.64. It is a per-O-methyl di-(hydrido) di-phospho di-hydrate, losing one $\mathrm{H}^{+}$and gaining one $\mathrm{H}^{+}$ion. The molecule is a cellotetraose derivative.

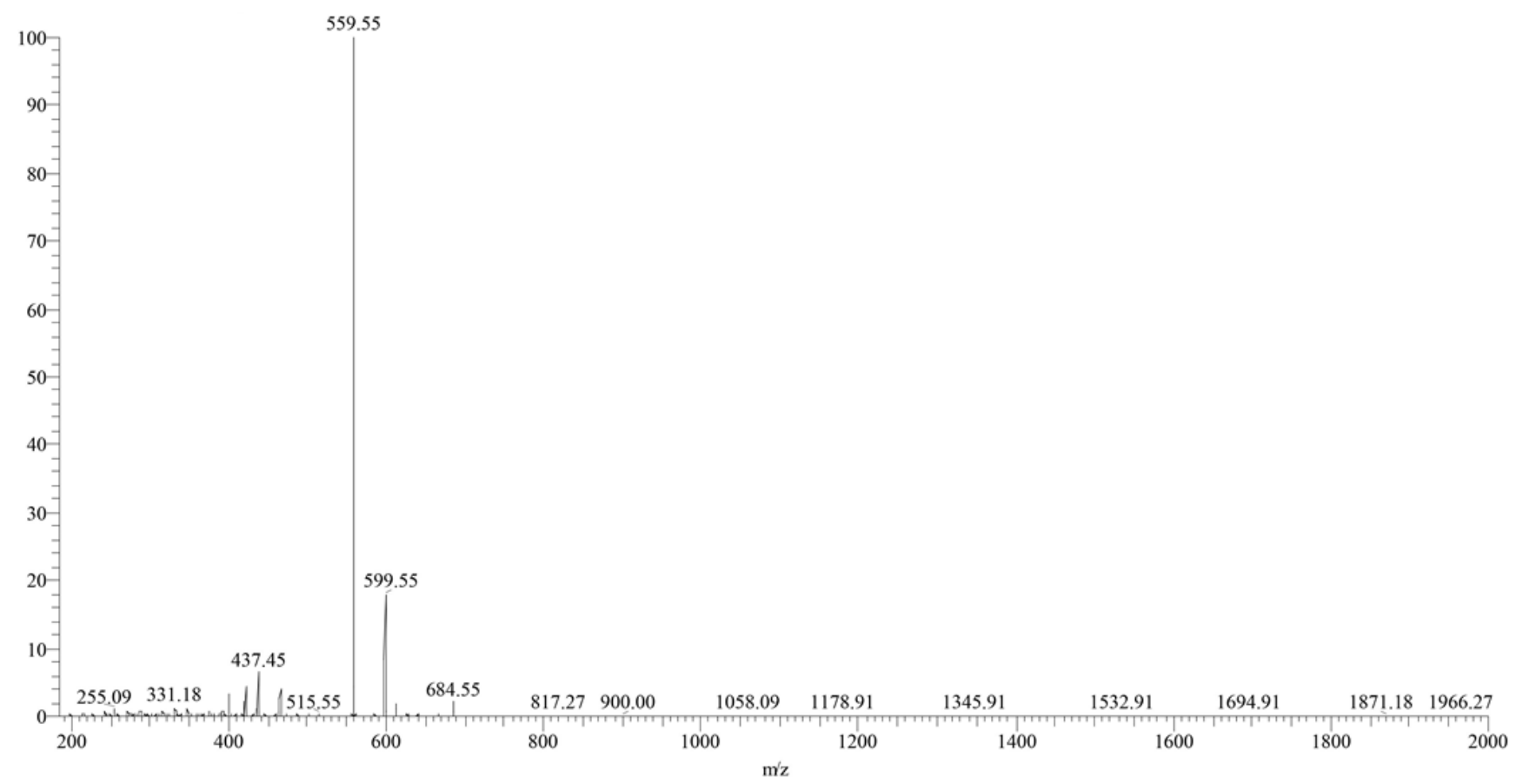

Figure 4. $M S^{2}$ of parent ion, $m / z 685.64$.

The parent ion, $\mathrm{m} / \mathrm{z}$ 685.64, was subjected to $\mathrm{ms} / \mathrm{ms}$ and its spectrum is shown in Figure 4. 


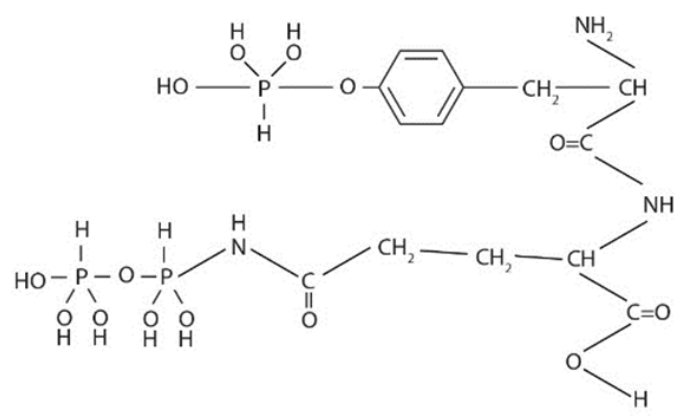

$$
\mathrm{C}_{14} \mathrm{H}_{28} \mathrm{~N}_{3} \mathrm{O}_{14} \mathrm{P}_{3}
$$

\section{$-2 \mathrm{H}+2\left(\mathrm{Na}^{+}\right)$}

599.27 calculated

599.55 found

$\Delta=0.28 \mathrm{amu}$
$-\mathrm{H}_{2} \mathrm{O}-\mathrm{H}^{+}+\left(\mathrm{Na}^{+}\right)$

559.27 calculated

559.23 found

$\Delta=0.04 \mathrm{amu}$

Figure 5. Daughter ions, $\mathrm{m} / \mathrm{z} 559.23$ and $\mathrm{m} / \mathrm{z}$ 599.55, from parent ion, $\mathrm{m} / \mathrm{z}$ 685.64.

In Figure 5 two ions are of appreciable intensity, $\mathrm{m} / \mathrm{z}$ 559.23 and $\mathrm{m} / \mathrm{z}$ 599.55. Their structures are drawn in Figure 5. These two ions can be derived from the one structure in Figure 3. The tyrosine is substituted with derivatized phosphate ester. The sulfo derivative does not comply with the mass constraints and any reasonable structure for these ions. A method for the discernment of phosphate versus sulfate eaters, normally isobaric, has been reported. (6)

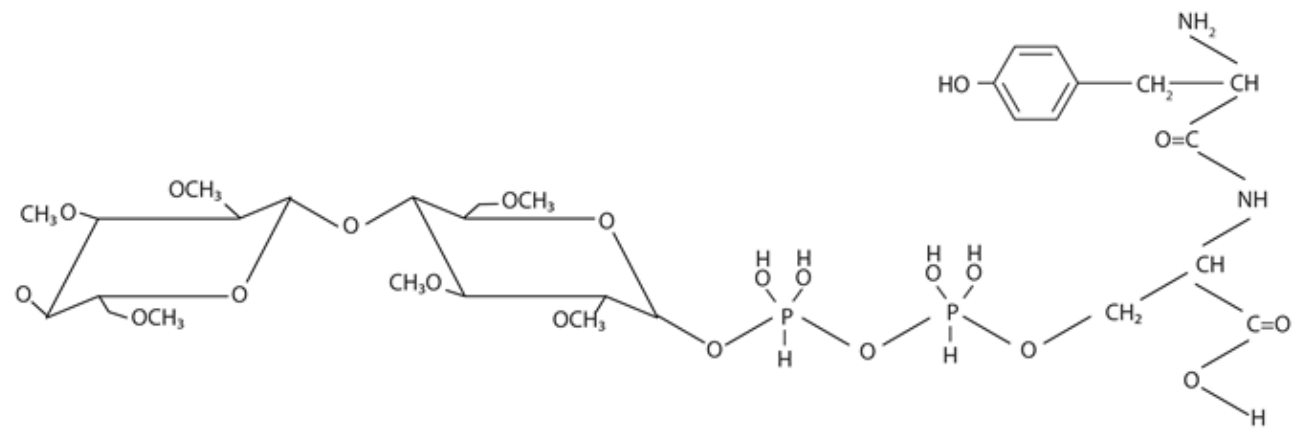

$\mathrm{C}_{30} \mathrm{H}_{53} \mathrm{~N}_{2} \mathrm{O}_{21} \mathrm{P}_{2}$

$-1 \mathrm{H}^{+}+2\left(\mathrm{NH}_{4}^{+}\right)$

\subsection{3 calculated \\ 437.36 found \\ $\Delta=0.03 \mathrm{amu}$}

Figure 6. Ion, $\mathrm{m} / \mathrm{z} 437.36 \mathrm{amu}$.

Tyrosine is not substituted with (hydrido) phospho hydrate.

Figure 6 depicts the structure of the ion, $\mathrm{m} / \mathrm{z}$ 437.36. The tyrosine is not phosphorylated (in derivative form) in this structure. 


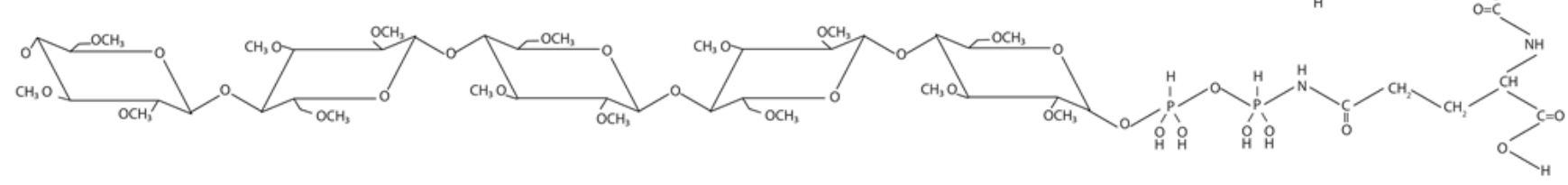

$$
\begin{gathered}
\mathrm{C}_{59} \mathrm{H}_{107} \mathrm{~N}_{3} \mathrm{O}_{39} \mathrm{P}_{3} \\
-2 \mathrm{H}^{+}+\left(\mathrm{NH}_{4}^{+}\right) / 2 \\
795.60 \text { calculated } \\
795.18 \text { found } \\
\Delta=0.42 \text { amu }
\end{gathered}
$$

Figure 7. Ion, $m / z$ 739.36, is characterized by a cellulohexaose.

In Figure 7 the structure for $\mathrm{m} / \mathrm{z} 795.18$ is a cellulopentaose derivative. It has the (hydrido) phospho hydrate substitution of tyrosine asparagine oligosaccharide dipeptide. Ion, $\mathrm{m} / \mathrm{z} 711.36$, is the cellotetraose derivative less $2 \mathrm{H}+$ ions and adds $3 \mathrm{NH}_{4}^{+}$ ions divided by 2 . The difference between calculated and found formula weight is well within acceptable variation.

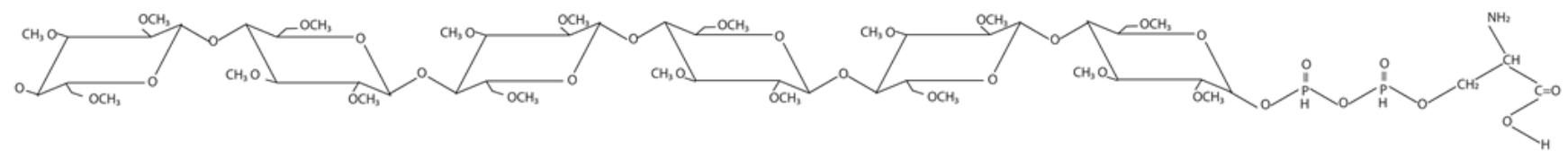

$$
\begin{gathered}
\mathrm{C}_{57} \mathrm{H}_{104} \mathrm{NO}_{37} \mathrm{P}_{2} \\
-1 \mathrm{H}^{+}+\left(\mathrm{Na}^{+}\right) / 2 \\
739.55 \text { calculated } \\
739.36 \text { found } \\
\Delta=0.19 \text { amu }
\end{gathered}
$$

Figure 8. Ion, $m / z$ 795.18, is a cellulopentaose which is linked to the derivatized di-phospho asparagine.

Figure 8 ion, $\mathrm{m} / \mathrm{z}$ 795.18, suggests a per-O-methyl cellulohexaose substituted with the asparagine amino acid linked to the oligossccharide by a di-(hydrido) di-phospho dihydrate.

Figure 9 The ion, $\mathrm{m} / \mathrm{z} 381.45$, is characterized by an asparagine linked di-(hydrido) di-phospho di-hydrate per-Omethyl disaccharide.

Attempts to determine the sulfo (di-hydrido) substitution failed, which suggests the robustness of the phospho/sulfo mass spectral discernment method previously noted. (6) The protein-cellulose linkage in plants is much like the linkage of carbohydrate to protein in bovine systems. The phospho tyrosine moeity in proteins in animals, like $\mathrm{K}$ casein, can be important in cell signaling by the action of protein kinases and phosphatases. 


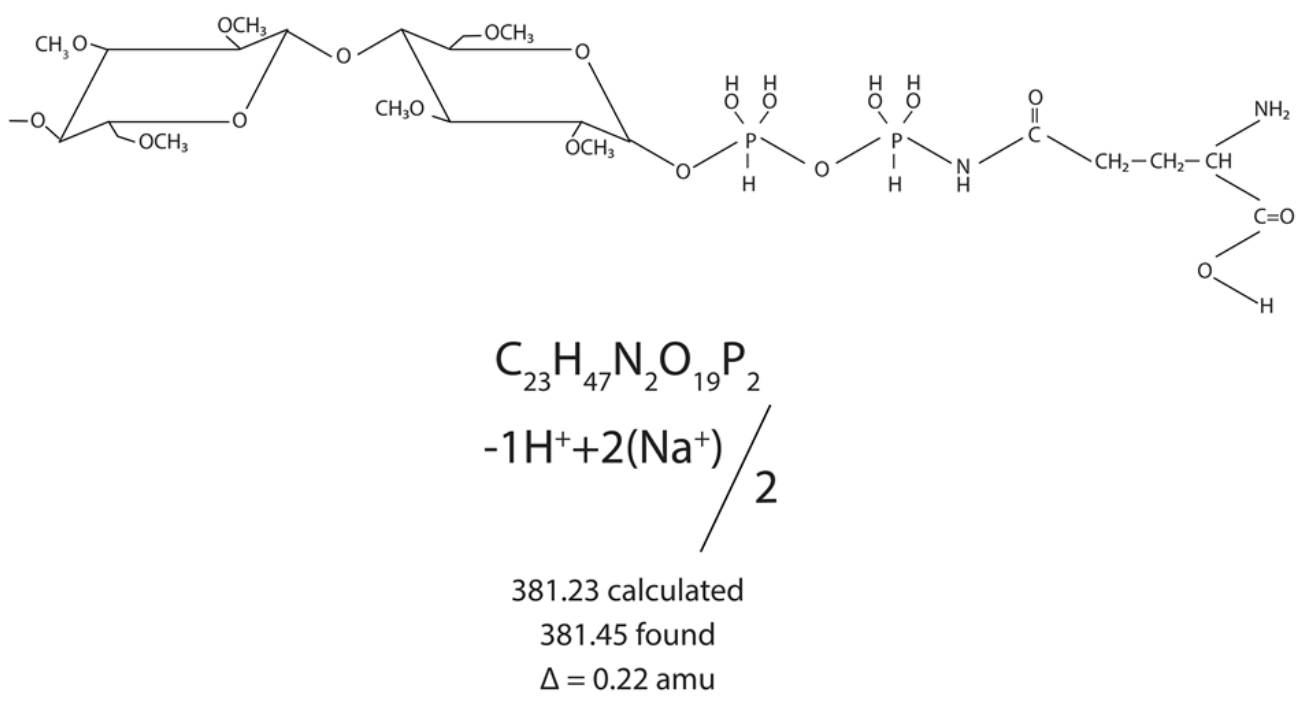

Figure 9. Ion, $m / z 381.45$ is an asparagine linked to per-O-methyl ceullulobiose.

It is evident from the Figures, detailing the structures of found ions that the protein cellulose linkage has been isolated This is also evident for $\mathrm{K}$ casein, bovine thyroglobulin and bovine milk. [15, 16, 17] It is not known under what conditions of the reaction produces the molecules by treatment with $\mathrm{NaBH}_{4}$ in $\mathrm{NH}_{4} \mathrm{OH}$. Except for one structure the amino acid, or dipeptide, connection to the cellulose, the di-phospho derivative is hydrated. The stability of the dihydrate can be explained. That is, with the loss of $2 \mathrm{H}_{2} \mathrm{O}$ molecules, the anhydro phospho group is produced. The $\mathrm{P}=\mathrm{O}$ double bond puts the non-bonding electrons on the $\mathrm{O}$ atom of the $\mathrm{P}=\mathrm{O}$ double bond in an antiperiplanar alignment with $\mathrm{C}-1$ to $\mathrm{O}-1$ bond of the sugar. This would make the $\mathrm{C}-1$ to $\mathrm{O}-1$ bond weaker. The $\mathrm{C}-1$ atom becomes more susceptible to attack by $\mathrm{H}^{-}$nucleophile, producing the 1,5 anhydro molecule. This phenomenon has been shown for $\mathrm{K}$ casein, bovine thyroglobulin and bovine milk. The hydrate is probably tetrahedral and thus their is no opportunity for antiperiplanar alignment. One explanation for the presence of the amino acid (dipeptide) linked to glycan is that $\mathrm{pH}$ drops when the reaction vessel is uncapped. It could be enough to hydrolyze the peptide and the di-(hydrido) di-phospho di-hydrate. Peptides can be hydrolyzed to amino acids or dipeptides at lowered $\mathrm{pH}$ and long reaction times. The $\mathrm{pK}_{\mathrm{a}}$ of the amide linkage is approximately 9.5. The evolution of $\mathrm{NH}_{3}$ gas from the $\mathrm{NH}_{4} \mathrm{OH}$ in the reaction mixture would drop the $\mathrm{pH}$ significantly.

The cellulo-peptide may be helpful in finding how the growing cellulose chain is anchored to protein.

\section{Conclusions}

A mild methylation method is detailed here, mild enough to allow isolation of phosphate-(derivatized)-linked glycanamino acid (dipeptide) linkages.

Novel chemistry is used; preparation of carbonate esters and conversion to methyl ethers with $\mathrm{NaBH}_{4} / \mathrm{NH}_{4} \mathrm{OH}$ aqueous solution.
Cellulo-oligosaccharides are linked to serine and asparagine.

Glucan phospho-tyrosine serinyl or asparaginyl dipeptide was isolated.

The cellulose linkage to protein has been discovered using this mild methylation

\section{Acknowledgements}

The authors would like to acknowledge Isaac Woolery for his dedication and high quality work and character working even while ill with an assist to Tessa. Thanks go to Pastor Jeff Alvestad and Street Evangelist Ricardo Samiento and Pastor Beth Bachman Caufield.

\section{References}

[1] Bjorndal, H.; Hellerqvist, C.; Lindberg, B.; Svensson, S.; Gasliquid chromatography and mass spectrometry in methylation analysis of polysaccharides; Angewandte Chemie International Edition in English 9 (1) 610-619 (1970).

[2] Harris, P.; Henry, R.; Blakeney, A.; Stone, B.; An improved procedure for the methylation of oligossccharides and polysaccharides Carbohydrate research 127 (1) 59-73 (1984).

[3] Sowden, J.; The saccharinic acids Advances in carbohydrate chemistry 12 55-79 (1957).

[4] Hough, L.; Priddle, J.; Theobald, R.; The carbonates and thiocarbonates of carbohydrates; Advances in carbohydrate chemistry 15, 91-158 (1961).

[5] Madson, M.; Manufacturing of $\mathrm{MeOH}$, formaldehyde, formic acid and ammonium pentaborate tetrahydrate from carbon dioxide patent US 8,695,355 B2 (2014).

[6] Madson, M.; Method of discerning substitution of carbohydrate esters patent US 9,726,671 B2 (2017).

[7] Glinski, M.; Weckworth, W.; The role of mass spectrometry in plant systems Mass spectrometry reviews 25 (2) 173-214 (2006). 
[8] McQuire, C.; Roseman, S.; Enzymatic synthesis of the protein hexosamine linkage in sheep submaxillary mucin; Journal of biological chemistry 242 (16) 3745-3747 (1967).

[9] Zhang, Y.; Zhang, P.; West, C.; A linking function for the cellulose-binding protein SPBS in the spore of Dictyostelium aiscoideum Journal of cell science 112 (23) 4367-4377 (1999).

[10] Shinohara, H.; Ogawa, H.; Matsubaychi, H-S.; Tyrosine sulfated glycopeptides involved in cellular proliferation and expansion Proceedings of the National Academy of Sciences, USA 104 (46) 18333-18338 (2007).

[11] Denu, J.; Stuckey, J.; Saper, M.; Dixon, J.; Form and function in protein dephosphorylation Cell 87 (3) 361-364 (1996).

[12] Nadam, D.; Knutson, E.; Lo, R.; Renig, N.; Exploration of cell signaling machinery activation of macrophage phospho tyrosine phosphatases as a mechanism of molecular microbial pathogenesis Journal of leukocyte biology 67 (4) 464-470 (2000).

[13] Mitho, S.; Boersema, I.; Berke, L.; Snel, B.; Heck, A.; Menke,
E.; Targeted quantitative phospho proteome approach for the detection of phospho-tyrosine signaling in plants Journal of proteome research 1 (1) 438-448 (2012).

[14] Christus, J.; Madson, M.; Possible treatment of Mycobacterium lepramatous with bovine milk World journal of food science and technology 2 (1) 55-61 (2018).

[15] Christus, J.; Madson, M.; Possible mimics of Duffy Binding Protein-ll for Plasmodium vivax binding endothelial cells or binding of Plasmodium falciparum by mimicking epitope on erythrocyte binding antigen-175 A World journal of food science and technology 2 (2) 44-51 (2018).

[16] Christus, J.; Madson, M.; Preparation of possible P selectin inhibitor from bovine thyroglobulin, (di-hydrido) sulfo hydrate 1,5 anhydro L-fucitol. World journal of food science and technology accepted for publication (2019).

[17] Richmond, T.; Sommerville, C.; The cellulose synthase superfamily Plant physiology 124 (2) 495-498 (2000).

[18] Endler, D.; Persson, S. Cellulose synthases and synthesis in Arabidopsis Molecular plant 4 (2) 199-211 (2011). 